\title{
IMPLEMENTATION AND PRACTICE OF INDIGENOUS RIGHTS: THE CASE OF THE MAYAN GROUP OF THE STATE OF QUINTANA ROO
}

\author{
JOSÉ ISRAEL HERRERA ${ }^{1}$
}

\begin{abstract}
Since 1997, the Mexican government has founded in the province of Quintana Roo a traditional style of justice instituted on a previous indigenous Mayan traditional legal system. This article provides a reflection about the way the Mayan justice has been recognized and implemented in the state of Quintana Roo, based on the incorporation of the rights derived from the ILO Convention 169 signed by Mexico in the last century. Mexico possesses and recognizes the Mayan legal system, but with some additions which causes the existence of two different structures the traditional and the new one which coexist in the same social field at the same time.
\end{abstract}

Keywords: Recognition; human rights; Maya; Mexico; Convention 169

Summary: I. INTRODUCTION; II. THE MAYA ETHNIC GROUP: BRIEF CHARACTERISTICS AND SOCIAL ORganizATION; III. THE TRADITIONAL MAYA LEgAL AND JUSTICE ORgANIZATION; IV. THE WAY THE TRADITIONAL MAYA INSTITUTIONS OF ADMINISTRATION OF JUSTICE ARE LEGALLY RECOGNIZED IN QUINTANA RoO; V. The INDigenous Judicial COUNCIL In QuinTANA RoO; VI. MAGISTRATE OF INDIGENOUS AfFaiRs; VII. MATERIAL AND PERSONAL JURISDICTION OF TRADITIONAL COURTS OF QUINTANA ROO; VIII. TRADITIONAL JUDGES; IX. PROCEDURAL RULES; X. CONCLUSION: CAN WE TALK OF AN IMPROVEMENT OF INDIGENOUS RIGHTS? XI. REFERENCES.

\section{INTRODUCTION}

In 1990 the Mexican government ratified the ILO Convention 169. This legal action helped to establish different measures to assure the implementation of human and indigenous rights in the country. All the Mexican legal system was modified to introduce the new group of rights this convention brought.

"In the early 90's the government signed the Convention 169 on Indigenous and Tribal Peoples in Independent Countries of the International Labour Organization that is replacing the Convention 107 of the same organization and doing away with the assimilative thrust of this former convention 107. Mexico was in a period of countless amendments and structural reforms designed to bring the country to a first world in a very brief period, to ameliorate the country's international reputation while the Free Trade in North America was approved. One

\footnotetext{
${ }^{1}$ Centre for Legal Studies of the Autonomous University of Campeche. Member of the National Council for Sciences and Technology of Mexico (CONACYT) - Level 1 (jiherrer@uacam.mx).
} 
of the main concerns of the government of the day was to silence the claims of indigenous groups that after almost five hundred years of the first European contact, still were the most neglected, abused and least developed parts of the population. The signing of the Convention 169 would show that the rural area accepted them in judgment and was doing its best to rectify preceding injustices” (Herrera, 2015: 69 - 70).

Assies cited by Herrera 2015, comments: "In 1989 it adopted the new ILO Convention 169. Mexico was the foremost Latin American nation to ratify the Convention, although it was to propose itself as a progressive nation in the international sphere. Inside the country the ratification went almost unnoticed.” (Assies, 2003: 75 mentioned in Herrera, 2015: 70)

De la Peña coincides with a similar scene, noting that in 1989 this document was ratified because of international pressure and political-economic concerns and not because the government studied the indigenous case as an instance of major care. Mexico ratified the convention in 1991, when former President Salinas (1988 - 1994) was interested in gaining legitimacy for his government both within Mexico and beyond. De la Peña notes that the changes also had strong relations with international political and economic circumstances and concerns of the government of the day. (Herrera, 2015: 70)

Also, the World Conference on Human Rights (14-25 June 1993, Vienna, Austria) got an enormous influence on the Mexican legal system.

On 25 June 1993, representatives of 171 States adopted by consensus the Vienna Declaration and Programme of Action of the World Conference on Human Rights... presenting to the international community a common plan for the strengthening of human rights work around the world. The Vienna Declaration and Program of Action marks the culmination of a long process of review and debate over the status of human rights machinery in the world. It also marks the beginning of a renewed effort to strengthen and further implement the body of human rights instruments that have been painstakingly constructed on the foundation of the Universal Declaration of Human Rights since 1948.

The Conference took historic new steps to promote and protect the rights of women, children and indigenous peoples by, respectively, supporting the creation of a new mechanism, a Special Rapporteur on Violence against Women, subsequently appointed in 1994; recommending the proclamation by the General Assembly of an international decade of the world's indigenous peoples , which led to the proclamation of two decades (1995-2004 and 20052014); and calling for the universal ratification of the Convention on the Rights of the Child by the year 1995. As of today, all countries, except for Somalia and the United States of America, have ratified the Convention. The 
Vienna Declaration also made concrete recommendations for strengthening and harmonizing the monitoring capacity of the United Nations system. (United Nations, 2017).

One of the main results of the World Conference on Human Rights was the proclamation of the First International Decade of the World's Indigenous People (19952004).

The International Decade of the World's Indigenous People (1995-2004) was proclaimed by the General Assembly in its resolution 48/163 of 21 December 1993 with the main objective of strengthening international cooperation for the solution of problems faced by indigenous people in such areas as human rights, the environment, development, education and health. The theme for the Decade is “Indigenous people: partnership in action”. In the same resolution, the General Assembly requested the Secretary-General to appoint the Assistant Secretary-General for Human Rights as the Coordinator of the Decade and established the Voluntary Fund for the Decade to assist the funding of projects and programmes which promote the goals of the International Decade of the World's Indigenous People. In its resolution 52/108, the General Assembly appointed the High Commissioner for Human Rights as Coordinator of the Decade. In its resolution 49/214 of 23 December 1994, the General Assembly adopted the short-term program of activities for 1995. The comprehensive program of activities was adopted by the General Assembly in its resolution 50/157 of 21 December 1995. The General Assembly also authorized the establishment of the Voluntary Fund for the International Decade for the purpose of financing projects and programmes during the Decade (United Nations, 2017b).

All of them made such a great influence over the Mexican legal system, especially for the state of Quintana Roo where the legislators decided to implement an indigenous legal system based on the Mayan Justice. So, in 1997 the state of Quintana Roo, after a couple of years of discussion, decided to carry out a fresh direction to accept and recognize the way the Mayan justice was being performed and mixed booth systems the traditional one and the state one. This state decided to carry out an indigenous legal system based on a previous traditional system under a Mayan vision, using part of the previous Mayan military and religious structure that still prevail in the area and that has been operating in the area for decades. The government decided to base the decision of creating this new system suing this convention to justify its implementation. 


\section{THE MAYA ETHNIC GROUP: BRIEF CHARACTERISTICS AND SOCIAL ORGANIZATION}

The word "Maya" defines an ethnic group that lives in the Mexican states of Yucatan, Campeche, Quintana Roo, Tabasco, Chiapas, Oaxaca and the countries of Belize, Guatemala, Honduras, as well as the western part of El Salvador. (Serrano 2003). The present Mayan society is widely extensive and complex. Within the Yucatan Peninsula society, we find four categories of people: whites, noble mestizos ${ }^{2}$ and the rebels.

The last group is formed by the "rebel macehuales". They are the descendants of the fighters of the Caste War of 1847. All of them are organized around the cult of the "Talking Cross" -the same that lead them through war. They still pray at their ceremonial centres and practice their old religion. It is estimated that this group embodies about 10,000 persons in the state of Quintana Roo.

The Mayan group of the Yucatan Peninsula is spread over the three entities with a geographically uneven population. "As a result, by 1930, to speak only of modern times, Yucatán had 380096 inhabitants, while Campeche had 84630 and Quintana Roo hardly exceeded 10 000. Today the differences have grown less: for the year 2000 Yucatan was in the lead with 1,658,210 inhabitants, Quintana Roo had 703536 inhabitants in 1995 and 874 963 in 2000. Campeche moved into third place with 690689 inhabitants in 2000” (INEGI 2001). The Maya population in the state of Yucatan forms 59.2\% of the total population. This means most of the population is Maya.

\section{THE TRADITIONAL MAYA LEGAL AND JUSTICE ORGANIZATION}

The history of the Maya society has been long and complex as they were part of the process of Mexico becoming a state, its independence from the Spanish crown, external and internal wars, the Mexican Revolution and the following public policies that were designed for them.

On arrival of the conquistadors, the Maya resisted the invasion; the Spanish took nineteen years to give up the north and middle section of the Peninsula of Yucatan, while some eastern states, northeasters and southern rebels remained physically and culturally apart from the Spanish dominion. The Spanish imposed a government of indigenous people called "encomienda", which permitted to master the native workforce, the collection of taxes and recruitment of the population. In the second half of the eighteenth century the "encomienda" system was replaced by corn farming and cattle ranching through which the natives were underpaid for their services. ${ }^{3}$

\footnotetext{
${ }^{2}$ Mestizo denotes a person who is half-blood Maya and Spanish.

${ }^{3}$ Bastarrachea Manzano, Ramón. http://www.cdi.gob.mx/ini/monografias/mayas.html.
} 
They lived under an eternal debt with the proprietor of the kingdom because they had to compensate for everything they demanded. Thus, the monetary values were fixed by the owners to make it costly. And this debt goes from generation through generation.

The continuous and systematic exploitation of indigenous people, produced many social problems and popular discontent was increasingly growing. Thus, in 1847, the same year as the United States of America invaded Mexico, the so-called “Caste War" (1847 1901) in which the Maya, who were suffering from oppression, domination and destruction of their structures and foundations, organized a revolt. They "paled in a military, spiritual, social organization that obtained significant victories. After three years of warfare, the guerrillas came to besiege the cities of Merida and Campeche. But insurgent troops withdrew to return to farm their crops, so the Yucatec's saw the opening to take advantage and recover militarily." 4

The Caste War reshaped the way of living of the Yucatec Maya in the states of Campeche, Yucatan and Quintana Roo. Many of the Mayans at that time fled into the forest and lived in that location for decades, where they developed their institutions and kept the same military -religious structure used in the Caste War. They copied and took after the names of the Mexican military structure of the 19th century, such as captains, sergeants, corporals and others.

The Caste War reshaped the way of living of the Yucatec Maya in the states of Campeche, Yucatan and Quintana Roo. Many of the Mayans at that time fled into the forest and survived in that location for decades, where they developed their institutions and kept the same military -religious structure used in the Caste War. They copied and took after the names of the Mexican military structure of the 19th century, such as captains, sergeants, corporals and others.

"In the central region of the state of Quintana Roo and some in the easterly division of the Yucatan and around the city of Valladolid the traditional authorities derive from the Caste War organization, with its system of safeguards in each of the residential areas that established "military companies” formed by married men, who defended a military structure, from corporals to commanders. Moreover, each community appoints its own local authorities. Most significant, nevertheless, are the "military companies" which still runs in the ceremonial centres in the region.” (Ruz 2006: 57)

At these times, this structure holds only in the province of Quintana Roo, because in the state of Yucatan and Campeche, the minuscule pieces of the structure were wiping out and did not realize it until today. In the residential areas, the individual responsible for the

\footnotetext{
${ }^{4}$ Bastarrachea Manzano, Ramón. Opus Cit.
} 
disposal of justice is the head of the village, ranch, plantation or rural area or other senior family members and lastly, the boss or the proprietor of the land.

\section{THE WAY THE TRAditional MAYA INSTITUTIONS OF ADMinistration of JUSTICE ARE LEGALLY RECOGNIZED IN QUINTANA ROO.}

In the jungle of Quintana Roo, this structure survives to this day. The traditional Maya institutions of administration of justice are at once acknowledged by the Indigenous Justice, Law Act of the State of Quintana Roo. This Act incorporates most of these traditional institutions within the official justice system, but also imposes conditions and formalities for accepting their verdicts. Ace of the postulations that the law has established, is that indigenous judges voted by the communities under direction of the Superior Court of Quintana Roo.

Not all the members of the religious-military-judicial have been formally incorporated into the new structure, and there is also some of them who are not mentioned in the law, such as Mayan priest and prayers. Nevertheless, these priests and people in the military judicial structure are still functioning in their traditional ways regardless the new structure. This is attributable to the fact that the Indigenous Justice, Law does not deal with the entire spectrum of tasks done by Maya authorities and particularly does not cover military or religious issues explicitly. They practise rites associated with harvest and rains, while the military keep safeguarding centres and practising ceremonial rites related to holy men, ensuring the security of the community, as well as exercising justice among their equals. This means these traditional institutions of cultural reproduction keep going as before as a parallel phenomenon to the new official position of Mayan judges.

The Caste War began in 1847. It had as a main purpose for the Maya rebels to regain their autonomy and to eliminate the "foreigners" of the entire peninsula of Yucatan (Villa, 1987). Because of the war, the Mayan adopted a military formation, where men formed "companies." On the crest of that organization was the chief minister of the Talking Cross, he was also appointed governor and his office was for life. Each company had a group of leaders with military ranks ranging from Commander to Privates (Villa, 1987) regulation:

In view of this situation it is possible identify two levels of Mayan institutions of

1) The traditional system

2) The one recognized in the Indigenous Justice, Law of the State of Quintana Roo.

The first system, the traditional, is formed by the religious, military and judicial institutions. They serve the purpose of guarding the Talking Cross, the ceremonial centres, which had led the Mayas into the revolt and for administration of justice in the region. The 
hierarchy has been established as follows: Generals, Captains, Lieutenants, Sergeants, Corporals, Soldiers, Priests, Prayers, Scribe, Gentlemen.

In Quintana Roo there are traditional centres where the Mayan people venerate their Gods, pray or celebrate traditional marriages and baptisms. Also, they keep several images of their "saints", their holy cross. These religious images were acquired as gifts, bequests or as trophies of war. The traditional centres in Quintana Roo are: Tixcacal Guardia, Chancá Veracruz, Chumpón, Tulúm, Cruz Parlante, and those recognized by the High Maya Council. $^{5}$

The present structures are built on a system of guards in all the communities called "companies" formed by honourable married men, who maintained a military structure, from corporals to commanders. Moreover, each community appoints its own local authorities. "This form of ethnic organization is focused on the worship of the cross. Each family maintains a cross of the family and each community also has its own community cross." (Ruz 2006: 57)

\section{The Indigenous Judicial Council In Quintana Roo.}

The traditional indigenous justice system established in 1996 is integrated by the Indigenous Judicial Council (IJC), a Magistrate of Indigenous Affairs (MIA) and the Mayan Generals.

The Indigenous Judicial Council is an institution composed of five Maya generals who counsel the judges and became a bridge between the traditional structure and the state. This council is an institution that works more as an advisor than a decision maker. This Indigenous Judicial Council has three basic functions that involve the supervision, training and orientation of traditional judges. The Maya generals maintain contact and periodic deliberations with the judges and the magistrate.

The Superior Court of the state of Quintana Roo has certified these generals as part of the state judicial system. In its capacity, it incorporates the Mayan general counsel to the state judicial system. The state recognizes and accepts the dual character of the indigenous council and the state indigenous system.

The Indigenous Justice Law (Quintana Roo) legitimises some of the traditional activities of the administration of justice the Generals have been executing. Contrary to what might be expected, the Generals do not consider their actions as limited, but extended. They sense that they are now in charge of more people due to their belonging to the Indigenous Judicial Council in Quintana Roo, which moreover allows them to take part in an institution that gives them visibility.

\footnotetext{
${ }^{5}$ This according to the article 45 of the Law of Rights, Culture and Organization of the state of Quintana Roo.
} 
Their traditional activities have been extended into official state justice and indigenous laws have been accepted by the state. This allows the Generals to access another level of justice which gives them political influence over state authorities.

The Indigenous Justice Law of Quintana Roo states in its article 8 an Indigenous Judicial Council in Quintana Roo for supervision, training and orientation of the traditional judges. It will be headed by a Magistrate of Indigenous Affairs chosen by the Superior Court of Justice of Quintana Roo. The council shall have five members selected from each of the Mayan ceremonial centres. The council will check the actions of all traditional judges and of the Magistrate of Indigenous Affairs and will provide the necessary means to function make all traditional judges working properly. Article 9 states that the Superior Court of the State, will select the traditional judges. All judges must be outstanding members of the community, who can speak Mayan language and know the uses, customs and traditions of their community.

\section{MAgistrate OF INDigenous AfFAirs.}

This magistrate has a dual role in the scheme of the Indigenous Justice Law Quintana Roo. On the one hand, he is responsible for hearing appeals from decisions handed down by the indigenous judges, and second, to organize the indigenous justice system through the organization of the courts. The MAI organizes, manage and coordinate the annual budget, policies to be followed, and election of judges, among other functions.

The present magistrate, is the central authority and the axis around which revolves the administration of indigenous justice. Having to deal both with the traditional system and the judicial officer of the state of Quintana Roo, he becomes the interpreter between both systems making him the key figure of traditional indigenous justice.

This Magistrate holds the right to cancel, change or confirm the decision of the judges under an appellation process mentioned by the law. The law states in its article 30 "The disagreements that may arise against the traditional judges in the exercise of their function will be dealt by the Magistrate of Indigenous affairs. The corresponding document will be submitted to the judge concerned within three days of the decision.”

Selected in 1997 the Magistrate has, until now, received only one case of an appeal from a person unconvinced with the decision of an indigenous judge. This case was not pursued, however, as the file was incomplete and the appellant did not persist. He also submits to the Superior Court of Quintana Roo the requests to install modern traditional judges in the communities. When the Superior Court of Quintana Roo approves the budget, and authorizes this new judge, then the MAI will consult the community to select a traditional judge who meets the requirements stipulated in the LJI. 
The MAI tries to meet with all members once a month. He sends a van to transport them to the place where they will be bringing together and to return them to their places after the meeting. At meetings, they talk about current problems in the communities, try to resolve problems of the prior month, and plan or set an agenda for the next one. The magistrate leads the meeting and drives the schedule. He listens, gives an opinion and advises the judges about the problems which must be solved immediately and their immediate tasks. He asks for the consensus among all the generals and the Magistrate decides the measures to be deployed. He also keeps an eye on personal activities of judges, their interests and needs, for example, materials or resources needed for the exercise of their activities.

\section{MATERIAL AND PERSONAL JURISDICTION OF TRADITIONAL COURTS OF QUINTANA Roo}

The Indigenous Justice Law of the State of Quintana Roo has ruled that judges have attributions and jurisdiction in three subjects, civil, family and criminal law.

The Indigenous Justice Law of Quintana Roo states

Article 14.- "The traditional courts have jurisdiction to hear and settle disputes in Civil, Family and Criminal matters”.

Article 15.- "In civil matters traditional judges have jurisdiction in the following matters, I. - contracts generating all kinds of rights and obligations, the monetary value of which does not exceed one hundred minimum wages. Included are also the obligations out of debts, up to the amount indicated and II.- The contracts stipulating obligations related to farming, livestock, poultry, beekeeping, hunting, fishing or forestry.

Article 16.- In family matters, traditional judges have jurisdiction in the following matters: I. - Maya marriages and its dissolution, which marriages for the application of indigenous law are hereby recognized officially as valid marriages and recognized by the Maya authorities and dignitaries of the place where the marriage was celebrated.; II.Custody, education and care of children. III.- Maintenance and IV.- Family disputes that affect the dignity, customs or traditions of the family.”

Article 17.- "In criminal matters, traditional judges have jurisdiction in the following offenses: I.- Stealing an amount not exceeding one hundred minimum wages; II.- cattle rustling of minor species (such as sheep, pigs and goats), as well as the cases referred to in fractions I through IV of Article 148 of the Penal Code for the State of Quintana Roo; III.Fraud in an amount not exceeding one hundred minimum wages; IV.- Breach of trust in an amount not exceeding one hundred minimum wages; V.- Abandonment of people; VI.Damage to the amount of one hundred minimum wages; VII.- All other crimes that are being prosecuted on the basis of a complaint under the Penal Code for the State of Quintana Roo.” 
In civil matters, the judges may hear conflicting about all types of contracts that will generate rights and obligations, whose benefits do not exceed approximately \$ 350 US. Within this category are included all credits or debts up to \$350 US. They can also address, commercial contracts related to livestock, poultry, bee-keeping, hunting, fishing or forestry that is raised. In criminal cases, the traditional courts have jurisdiction over the following crimes: damage, thievery, fraud in an amount that cannot exceed approximately \$ 330US. It also includes minor incidents with purchases, trading and cattle rustling and its derivatives. ${ }^{6}$

The judges have the power to attend minor faults such as verbal aggressions, misbehaviour in public, disrespect to an authority, or to a saint or an image, such as failure to show the respect a person must have in the ceremonial centres.

As for family matters, judges have jurisdiction to rule on custody, education, childcare, Maya divorce and alimony disputes. Also, they may deal with misbehaviour that goes against dignity and customs of family life. This is the first legislation in the country that recognizes the traditional jurisdiction in this area.

Divorce is a particularly sensitive area. Among the traditional judges, only three divorces have been dealt with (all in the same community of Chan Chen I). A case of divorces constitutes a paradoxical category because divorce runs counter to local values as in Maya communities’ marriages are perceived as being made for life.

“This month I had a lot of work. Many people came to me for separations. But all of them were well attended, and they are already pacified” (Reyes and Ek 2001: 94).

The quote above shows that the judge of this court prefers people not to insist on divorce; however, if parties push a little more, the judge will accept their wish to be divorced. Should the judge still not accept what the parties want, they may report him to the MAI to have him sanctioned and/or allow them to go on with the divorce. If necessary, if they do not wish to continue under the indigenous jurisdiction, then they can choose to bring their case to the Mexican state tribunals.

Let me stress again that the official competencies of the indigenous judges are not the same in the three states of the Yucatan Peninsula. For example, the Organic Law of Judicial Power of the State of Campeche, in Article 75-5 states that "under any circumstances conciliator's judges have jurisdiction over matters of trade or business, divorce, dissolution of marriage, paternity, adoption, guardianship, disputes over land tenure, temporary child custody, physical separation of spouses and determination and payment of alimony.” Here, family matters are excluded, while in the law of Quintana Roo, family cases do fall under the competence of the indigenous judges.

\footnotetext{
${ }^{6}$ Articles 17 and 18 of the Indigenous Justice Law of Quintana Roo 1997.
} 
To enforce their decisions, judges may choose and impose some of the following coercive and punitive punishments:

I. Warning;

II. Fines up to thirty minimum wages, (currently \$4 US dollars per day)

III. Jail up to thirty-six hours. ${ }^{7}$ following:

In criminal cases, judges may impose penalties and security measures like the

I. Monitoring of the authority;

II. $\quad$ Fines up to thirty minimum salaries;

III. Repair of damages;

IV. Working for the community;

V. $\quad$ Prohibition of going to a specific territory territorial area or live in it;

VI. Seizures of tools and objects related to the crime. ${ }^{8}$

The judges can pick up one, two, or more different sanctions to be imposed at the same time. For example, judges can order people to do some work in the community, pay damages and a fine. It is up to the judge and the situation.

To impose sanctions, judges consider the circumstances of the person, especially the economic one. Usually communities' economies are depressed; thus, monetary sanctions are not imposed frequently. In most of cases, people are ordered to do community work. This work is done in public places to show the person as an offender who just has been punished and this public humiliation is a punishment that hurts most.

Another important aspect of the sanctions of the Indigenous Justice, Law is the requirement that the judicial decisions do not violate human rights. To stress the importance of this requirement, the judges get recommendations and training courses run by the MAI, the CJI, or the Superior Court of Quintana Roo.

\section{TRADITIONAL JUDGES}

The region's indigenous judges are elected in community meetings convened by the Superior Court of Quintana Roo, the Magistrate of Indigenous Affairs and the Indigenous Judicial Council in Quintana Roo. Until today, there are 17 who have been chosen in this way. ${ }^{9}$ All the elected are men, although the invitation is not issued to any gender.

\footnotetext{
${ }^{7}$ Article 20 of the Indigenous Justice Law of Quintana Roo 1997.

${ }^{8}$ Article 21 of the Indigenous Justice Law of Quintana Roo 1997.

${ }^{9}$ Article 9. The Superior Court of the State, at the proposal of the Judicial Council of Indigenous Justice, will designate the traditional judges. The appointment of judges and magistrates of traditional indigenous affairs
} 
Until today, there are 17 Traditional Judges, five Mayan Generals and a Magistrate. The five Generals form a council of the indigenous judiciary. All traditional judges appointed for the area have a monthly compensation for their activities of a little less than the equivalent to \$ 200US. These judges are selected for life and no one has resigned. The only changes occurred because of death. In addition to their traditional activities as judges, they can engage in other jobs and activities, among which are blacksmith, mechanic, baker, Mayan priest, and peasants; being a farmer is the most frequent job the judges hold.

\section{Procedural RUles}

When a complaint is set up, the judge then issues a time and date for the parties involved in the dispute to appear in court. If the first summon is missed, the judge provides two more opportunities to have their case heard. If all three appearance dates are missed, the judge may send the case to an ordinary state court, and this generally means that it will take longer to resolve the dispute.

During the mediation, both parties to explain the case and their positions. Judges are limited at this point to be mediators. The mediation takes place in Mayan or Spanish or in both languages. If a party speaks only in Mayan or Spanish, the judge will be the translator and will give a voice to all the stakeholders. A crucial element of conciliation is that people are accompanied by members of their family. The judges are aware that usually a predicament, a felony, a transgression or an offense involves the whole family. The role of these family members is a crucial element in their way of trying to find a settlement. The judges take great care when family members are present at the mediation because people tend to favour and protect their relatives. Also, people may be influenced by the pressure coming from the family to act in one way or another.

Conciliations are based on consensus among the parties. The solution emerges from the parties involved and the judge. Legally, it depends on the parties whether they will submit their case to the indigenous judges and/or whether they want to continue their case there. The judges only deal with cases where people have chosen to submit their problem voluntarily. Parties can withdraw their case at any time. However, after the decision is settled it becomes a legally valid and binding decision.

"The word for the Indigenous people, in the communities of Quintana Roo, is worth a lot. The word is the truth” (Reyes and Ek 2001: 93-94).

shall be on upstanding members of the community, who speak the language and knows the uses, customs and traditions of their community, without having to qualify or have the constraints set Organic Law of the Judiciary of the State. Indigenous Justice Law of Quintana Roo. 
The Indigenous Justice Law LJI has declared this kind of justice as “alternative and volunteer". This law states in its articles six and twelve that the person has the choice of whether submit his case or not to the legal indigenous process. The LJI points:

Article 6.- The indigenous justice is an alternative to the ordinary judicial courts and judges of the common order, this jurisdiction will always be expedited under the terms and conditions agreed in the Political Constitution of the Mexican States, the States Constitution and ordinary laws.

Article 12.- If the parties, decide the mediation by the traditional judge to settle their differences by agreement, it shall be approved at a properly and execute a mandate of this decision.

All of this means that a person can decide where to deal with a case, with the traditional judge, or with the local (formal) authority. For example, in a case of theft, the offender can go to the state, municipal office of the town or to the federal or state prosecutor to start with a complaint. Also, he can go to the traditional judge of his community (if there is one there). This choice will be up to him.

When this person resolves attend with the traditional one, the conciliation procedure or investigation of the criminal behaviour will be started. However, if mediation is not set or if the person does not feel confident, do not know the existence of this justice, or just do not have the will to deal with the traditional justice, he still has the right to stop the process and continue with the state or federal justice.

Nevertheless, once the parties get an agreement under the traditional justice, this decision will be final, but only if they do not decide to appeal the decision to the MAI.

The MAI has tried to standardize and homogenize the agreements by issuing all of them with a "master model" with blank spaces to be filled with the data of individuals and the decision taken. This is also to help judges who have problems in reading and writing to document their activities, in which case, the judges ask an assistant to fill the record and read it in front of him. This because a few judges do not know how to write or read.

The Magistrate of Indigenous Affairs of Quintana Roo said: "We have tried to document all actions of the judges. Many times, they do not make records in cases such as gossips, rumours or tittle-tattle. Sometimes they hide the file or the case is settled in secrecy. I have tried to generate information to make comparisons, but it is a bit difficult, because they are very jealous of their private life. However, we have tried to support them by providing them with a master model to facilitate their work. (Reyes and Ek 2001: 94).

All the ceremonial centres, except X-Yatil, have Mayan priests who can marry people under a Mayan ceremony. They identify their church, masses, sacraments and rituals as belonging to the Mayan Catholic Church. This form of marriage is widespread among the 
population of the region. However, this has created problems in the relation between the state and the Mayan people because before 1996 the traditional marriages were not recognized as valid.

A Mayan person said: "I got married in Tixcacal and one day I had to do some paperwork with the city of Carrillo Puerto and a bureaucrat told me: Where did you get married? In the Ceremonial Centre of Tixcacal? Sorry, but that marriage is not valid. You must go to the civil registry office to get married again by a civil law" (Reyes and Ek 2001: 91-92).

However, the Indigenous Justice Law of Quintana Roo recognizes the Mayan marriage ceremony conducted in the ceremonial centres, as an official and valid marriage. Marriages have been made since ancient Maya times in the ceremonial centres by the Mayan priest in the presence of godparents, witnesses, and the spouses.

The services of the judges are free and only for weddings and baptisms they charge almost \$2.5US for issuing a certificate. If the couples do not have the money, it will be provided for free. The certificates begin with the words "Ceremonial Centre of (location)" Act of Marriage. They have also added stamps of the Mayan Catholic Church. This is a name used in the area to stress the Mayans have their own religion.

\section{CONCLUSION: CAN WE TALK OF AN IMPROVEMENT OF INDIGENOUS RIGHTS?}

The state of Quintana Roo has implemented a new legal system to fulfil indigenous rights to obtain their justiciability. This measure establishes two well differentiated structures that must live together, the old indigenous structure and the new official indigenous system. Both are still in a process of recognition of each other and a slow assimilation of the new structure.

This means the human rights can modify the way of living of an indigenous group in diverse ways. For instance, there is a new official traditional way of justice that did not exist before 1997. So, there is a huge debate Can this be called traditional? If is not inspired and came from the base, can this still be called indigenous? This resolution did not come from a prior consultation; it was imposed in all the area even when it changes their way of living.

This is a system that can be called as traditional official justice and as a new legal system, it will require time to develop and start a process of dialogue with both parts. What can be said is that if both parts dialogue with respect and in equal positions the system will help to implement properly the goal of helping to develop the indigenous rights in the area and part of the ILO Convention 169. All of this is framed under a well-known phenomenon called formal legal pluralism. 
This happens when "governments officially recognize the existence of distinct indigenous groups, ethnic or minority groups in their country and accord them the right to apply and develop their own institutions of administering justice” (Herrera, 2015: 69). "In the case of Mexico, the relation to these distinct communities has been shaped and reshaped by different historical circumstances and legal changes. Recently more interest has emerged in accommodating the grievances of the indigenous peoples in Mexico while also within the social sciences somewhat more attention is paid now to the issues involved" (Herrera, 2015: 69). "The restructuring of international political forces is in relation to processes of decolonization in the world. It also situates the grievances and social movements for autonomy and / or self-determination in Africa, Europe and Asia” (Valdivia, 1992: 111).

The existence of these proper indigenous regulatory institutions is due to circumstances like the absence of formal authority in those regions, the big distance to the state capital and the strong legitimacy of these institutions within the local communities. She discusses several examples of interlegality and forum shopping (Herrera, 2015: 70 - 71).

Though these judges appear to belong to the system, at the same time they are outsiders. They do not have an official remuneration or allowances as an official state judge would. They don't receive social services for themselves or their family. They have no retirement program and if someone gets an accident, they are not taken care of by the state. The state pays them only monthly "bonuses" and accepts no further responsibility.

When the indigenous judges travel to other state offices or outside of their town, they are not always welcomed or respected by the formal authorities. The Magistrate of Indigenous Affairs prefers to accompany the indigenous judges to avoid potential disrespect from the local authorities. The Magistrate of Indigenous Affairs says that little by little the work of the indigenous judges has been reaching the municipalities of the region, but still they are relatively unknown to other higher levels of the state government administration.

Are we talking here on an injustice to get justice? Governments usually start the implementations of human rights when a new treaty is signed. But the results are often ambiguous or uncertain. Here human rights were implemented to try to get a better justice. So, it means also that on the other hand, it must be recognized that in has helped to relieve the justice problems in the area such the distance from formal authorities, the use of Spanish in formal proceedings, being under a complicated formal system having now judges who speak their language, and live in their communities. Also, as time passes by, the new judges will start to be traditional and people will see them as part of their way of living. 


\section{REFERENCES}

Assies, Willem, Gemma van del Haar and André Hoekema, eds. (1999). El reto de la diversidad. Pueblos indígenas y reforma del Estado en América Latina. Zamora, México / El Colegio de Michoacán.

Auriat, Nadia. (1995) “Pluralisme culturel et multiculturalisme.” In Lettre de most, n. 3, June. Online: <www.unesco.org/most/newlet3e.htm> [Accessed: 13th september 2017]

Barrera, L. (2001) Inicios de una jurisprudencia respetuosa de la cultura maya en Yucatán, In Krotz E. (ed). Aproximaciones a la antropología jurídica de los mayas Peninsulares. 107-111. Mérida: Programa de las Naciones Unidas para el Desarrollo \& Universidad Autónoma de Yucatán.

Bastarrachea, M. (2009) Mayas de Yucatán, [online] México: Comisión para el Desarrollo de los Pueblos Indígenas. http://www.cdi.gob.mx/ini/monografias/mayas.html. [Accesed: 13th september 2017].

Bonfil Batalla, G. (1991) México profundo: una civilización negada. México: Grijalbo.

Buenrostro Alba, M. (2006) La justicia indígena de Quintana Roo impartida por los jueces tradicionales mayas. Oaxtepec: Paper presented at the 5th Congress of the LatinAmerican Network of Legal Anthropology. October 16-20, 2006.

(2008) Cambios constitucionales en materia indígena en la Península de Yucatán: El caso de los jueces tradicionales mayas de Quintana Roo. Paper presented in the seminar ¿Una década de las reformas indígenas? Multiculturalismo y Derechos de los Pueblos Indios en México”. Mexico. September 11th, 2008.

Casares G. Cantón, R. et al. (1998) Yucatán en el tiempo. Tomo I. Mérida: Cares.

(1998b) Yucatán en el tiempo. Tomo II. Mérida: Cares.

(1998c) Yucatán en el tiempo. Tomo III. Mérida: Cares.

(1998d) Yucatán en el tiempo. Tomo IV. Mérida: Cares.

Chenaut, V \& Sierra T. (1992) El campo de investigación de la antropología juridica. Nueva Antropología. 43. 101 - 109.

Chenaut, V \& Sierra T. (eds.) (1995). Pueblos indígenas ante el derecho. Mexico: Centro de Investigaciones y Estudios Superiores en Antropología Social \& Centro de Estudios Mexicanos y Centroamericanos.

De la Peña, G. (1996). Nacionales y extranjeros en la historia de la antropología Mexicana. La historia de la antropología en México, fuentes y transmission. In Rutsch, M. (ed.) México: Universidad Iberoamericana \& Instituto Nacional Indigenista \& Plaza y Valdés. 
(2006) A new Mexican nationalism? Indigenous rights, constitutional reform and the conflicting meanings of multiculturalism. In Nations and Nationalism. 12. pp. 279-302.

Escalante, Y. (2002). La experiencia del peritaje antropológico. México. Instituto Nacional Indigenista \& Secretaría de Desarrollo Social.

Gabbert, W. (2003) La interacción entre derecho nacional y derecho consuetudinario en América Latina. In Beatriz Pérez G. \& Dietz G. (eds.) Globalización, resistencia y negociación en América Latina. Madrid: Los libros de la Catarata.

(2006) Los juzgados indígenas en el sur de México. Oaxtepec: Paper presented at the 5th Congress of the Latin-American Network of Legal Anthropology. October $16^{\text {th }} 2006$.

Griffiths, J. (1986) What is legal pluralism? In Journal of Legal Pluralism and Unofficial Law. 24, pp. 1 - 55.

Guerrero García, F. J. Jerónimo et al. (2007). La Vigencia de los Derechos Indígenas en Mexico. Análisis de las repercusiones jurídicas de la reforma constitucional federal sobre derechos y cultura indígena en la Estructura del Estado. Comisión Nacional para el Desarrollo de los Pueblos Indígenas. Mexico City.

Guevara Gil, A. (1999). Apuntes sobre pluralismo legal. In Ius et Veritas. Revista de los estudiantes de la Pontificia Universidad Católica de Perú. 19. pp. 286-304.

Herrera, J. I. (2001) Algunas características del derecho maya. In Aproximaciones a la antropología jurídica de los mayas Peninsulares. In Krotz E. (ed). Merida: Programa de las Naciones Unidas para el Desarrollo / Universidad Autónoma de Yucatán.

(2010) Peritaje Antropológico. Sus realidades e imaginarios como prueba judicial federal. Merida: J.I. Herrera \& Manejo Cultural.

-(2013) Una aproximación a los expedientes de conciliación de los Jueces Tradicionales de Quintana Roo.” In Temas Antropológicos, Vol.35, pp..143-170.

(2013) Una aproximación etnográfica - legal al sistema de justicia tradicional del Estado de Quintana Roo. In: Tohil. Vol.27, pp. 7-30.

(2014) Justicia tradicional oficializada en la Península de Yucatán.” In: Diario de Campo. Vol.1, pp. 1-10.

(2015) La defensa cultural en los procesos judiciales federales a la etnia Maya Peninsular: Una aproximación teórico práctica. In: Krotz, E. (ed.) Sociedades Mayas y Derecho. Mérida: UNAM / PROIMMSE / IIA / MODELO, pp.171-184.

Hoekema, A. (2005). European legal encounters between minority and majority culture: Cases of interlegality. In Journal of Legal Pluralism. 51, pp. 1-28. 
Instituto Nacional de Estadística, Geografía e Informática. (2001). Tabulados Básicos. Aguascalientes: Instituto Nacional de Estadística y Geografía.

(2003) Anuario estadístico del Estado de Yucatán 2003. Aguascalientes: Instituto Nacional de Estadística, Geografía e Informática.

(2010) Hablantes de lengua indígena en México. Aguascalientes: Instituto Nacional de Estadística, Geografía e Informática. Available from: http://cuentame.inegi.org.mx/poblacion/lindigena.aspx?tema=P [Accessed: 13th september 2017]

Krotz, E. (1988) Antropología y derecho. In México Indígena. 25, pp. 6-14.

(1994) Alteridad y pregunta antropológica. In Alteridades. 8, pp. 5-11.

(1997) Aproximaciones a la cultura jurídica en Yucatán. In Aspectos de la cultura jurídica en Yucatán. Krotz E. (ed.) Mérida: Consejo Nacional para la Cultura y las Artes \& Maldonado.

(2003) "El estudio de la cultura en la antropología mexicana: una visión panorámica.” In José Manuel Valenzuela Arce, coord., Los estudios culturales en Mexico, pp. 80-115. Fondo de Cultura Económica. Mexico City.

Krotz, E. (ed.) (1997). Aspectos de la cultura jurídica en Yucatán. Mérida: Consejo Nacional para la Cultura y las Artes \& Maldonado.

(2001) Aproximaciones a la antropología jurídica de los mayas Peninsulares. Mérida: Programa de las Naciones Unidas para el Desarrollo \& Universidad Autónoma de Yucatán.

(2002) Antropología jurídica: perspectivas sociales y culturales en el estudio del derecho. Mexico: Autonomous Metropolitan University - Iztapalapa \& Anthropos \& International Labor Organization.

Merry, Sally Engle. (2003) “From law and colonialism to law and globalization.” In Law and Social Inquiry, vol. 2, n. 2, April, pp. 569-590.

DOI: https://doi.org/10.1111/j.1747-4469.2003.tb00206.x

Moore, Sally Falk. (2001). "Certainties undone: Fifty turbulent Years of Legal Anthropology.” In: Journal of the Royal Anthropological Institute, n. 7, pp. 95116.

United Nations. (2017) World Conference on Human Rights, 14-25 June 1993, Vienna, Austria. Available from:

http://www.ohchr.org/EN/AboutUs/Pages/ViennaWC.aspx [Accessed: 13th september 2017] 
United Nations. (2017b) International Decades of the World's Indigenous People. Available from: http://www.ohchr.org/EN/Issues/IPeoples/Pages/InternationalDecade.aspx [Accessed: 13th september 2017]

Orellana, René. (2004). Interlegalidad y Campos Jurídicos. Discurso y derecho en la configuración de órdenes semiautónomos en comunidades quechuas de Bolivia. Cochabamba: Huella editores.

Reyes, J. \& Pedro E. (2001) Solución de conflictos de acuerdo con la Ley de Justicia Indígena del Estado de Quintana Roo. In Aproximaciones a la antropología jurídica de los mayas Peninsulares. Krotz, E. Merida: Programa de las Naciones Unidas para el Desarrollo / Universidad Autónoma de Yucatán.

Ruz Lhuillier, A. (1989) Los antiguos Mayas. México: Fondo de Cultura Economica.

Ruz, M. H. (2006) Mayas. Primera parte. Pueblos Indígenas del México Contemporáneo. Mexico: Comisión Nacional para el Desarrollo de los Pueblos Indígenas \& Programa de las Naciones Unidas para el Desarrollo.

Serrano Carreto, E. et al. (ed.) (2002) Indicadores socioeconómicos de los pueblos indígenas de México 2002. Instituto Nacional Indigenista \& Programa de las Naciones Unidas para el Desarrollo \& Consejo Nacional de Población. Available from: http://www.cdi.gob.mx/index.php?id_seccion=91 [Accessed: 13th september 2017]

Simon Thomas, Marc. (2009) "Legal pluralism and interlegality in Ecuador: The La Cocha murder case.” In Cuadernos del CEDLA, vol. 24.

Sierra, M. T. (1997). Esencialismo y autonomía: paradojas de las reivindicaciones indígenas. In Alteridades. 14. pp. 131-143.

(2005) Derecho indígena y acceso a la justicia en México: Perspectivas desde la interlegalidad. In Revista IIDH. Instituto Interamericano de Derechos Humanos. 41. pp. 283-316.

Van de Sandt, Joris. (2003) Communal resource tenure and the quest for indigenous autonomy: on state law and ethnic reorganization in two Colombian resguardos. In Journal of Legal Pluralism, n. 48, pp. 125-162.

(2007) Behind the mask of recognition: defending autonomy and communal resource management in indigenous resguardos, Colombia. PhD Thesis. Faculty of Law. University of Amsterdam, Amsterdam.

DOI: https://doi.org/10.1080/07329113.2003.10756569

Villa Rojas, A. (1987) Los elegidos de Dios. Etnografía de los mayas de Quintana Roo. Mexico: Instituto Nacional Indigenista. 
JOSÉ ISRAEL HERRERA

\section{Legal Codes}

(1989) Indigenous and Tribal Peoples Convention - C169 of the International Labor Organization.

(1997) Indigenous Justice Law of the state of Quintana Roo.

(1997) Law of Rights, Culture and Indigenous Organization of the State of Quintana Roo” (2014) Mexican Political Constitution. México: Porrua. 